\title{
ANOTASI BIBLIOGRAFI \\ SMARTPHONE SEBAGAI MEDIA PEMBELAJARAN, MEDIA YANG \\ DIGUNAKAN UNTUK PEMBELAJARAN, TUJUAN BERPIKIR HISTORIS
}

\author{
OLEH \\ ASWATULLAH AL-AHMAD \\ Email : 1910111310014@mhs.ulm.ac.id \\ Program Studi Pendidikan Sejarah Falkutas Keguruan dan Ilmu Pendidikan \\ Universitas Lambung Mangkurat
}

Banjarmasin

H Susanto, H Akmal (2018). Efektivitas Penggunaan Aplikasi Pembelajaran Berbasis Mobile Smart Phone Sebagai Media Pengenalan Sejarah Lokal Masa Revolusi Fisik

Di Kalimantan Selatan Pada Siswa Sekolah. HISTORIA : Jurnal Program Studi Pendidikan Sejarah 6(2), 197-206.

Artikel ini menjelaskan kepada kita atau pun pembaca bahwa agar bisa meneliti sebuah efektivitas yang di menggunakan aplikasi pada sebuah pembelajaran yang bisa dilakukan menggunakan smartphone untuk tujuan sebuah media yang digunakan untuk melakukan penggenalan dari pada sejarah berbasis lokal didalam periode sebuah revolusi fisik pada Kalimantan Selatan. Dengan memakai metode yang bernama kuantitatif agar bisa berguna pada untuk desain pretest-posttest dengan pembagian kelompok satu pra-eksperimental dengan tujuan untuk peneliti melakukan sebuah pengujian efektivitas pada media agar bisa melihat pembandingan kepada peserta didik yang diuji pemahaman mereka saat menggunakan media sesudah dan sebelum mereka diberitahukan kegunaan serta cara pemakaiannya dengan benar.

H Susanto, H Akmal (2019). Media Pembelajaran Sejarah Era Teknologi Informasi (Konsep Dasar, Prinsi Aplikatif, dan Perancangnya). Program Studi Pendidikan Sejarah Falkutas Keguruan dan Ilmu Pendidikan Universitas Lambung Mangkurat.

Buku ini adalah buku materi untuk mata perkuliahan media pembelajaran sejarah. Didalam buku terkandung banyak sekali penjelasan mengenai 
materi-materi ajar yang tentu saja memiliki pembahasan mengenai media apa saja yang bisa gunakan dalam upaya pembelajaran sejarah, mengenai metode apa yang bisa gunakan oleh pengajar untuk mengajar peserta didik. Didalam buku ini juga menjelaskan mengenai cara pemakaian media yang bisa di gunakan saat belajar daring misal edmodo, zoom, dan lain sebagainya. Di buku ini juga menjelaskan tentang rangkain cara-cara untuk bisa menggunakan media, menjelaskan dengan detail sehingga kita bisa memahaminya, mengerti dan mengaplikasikan berbagai barang elektronik yang bisa digunakan sebagai media pembelajaran. Buku ini juga disusun dengan penjelasan yang lengkap mengenai konsep dasarnya, cara penggunaannya, serta perancangnya sehingga kita bisa mengaplikasikan buku ini sebagai panduan kita jika ingin membuat media pembelajaran yang inovatif.

M Z A Anis, H P N Putro, H Susanto, K P Hastuti, Mutiani (2020). Historical Thinking Model in Achieving Cognitive Dimension of Indonesian History Learning (Model Berpikir Historis dalam Mencapai Dimensi Kognitif Pembelajaran Sejarah Indonesia). Rumah/Arsip/ Vol 17 No. 7 (2020): PALARCH'S JOURNAL OF ARCHAEOLOGY OF EGYPT/ EGYPTOLOGY.

Artikel ini mengajarkan dan menjelaskan kepada kita agar bagaimana cara berpikir secara fenomenal yang telah di terapkan oleh negara maju sehingga kita yang menerapkan cara berpikir ini bisa membuat peserta didik di Indonesia berpikir kritis dan tidak kaku, walau pun tidak selamanya keberhasilan itu ada sebab banyak peserta didik yang masih beku tidak berpikir kritis dalam menghadapi pembelajaran sejarah yang tentunya akan membuat Indonesia terdorong untuk melakukan penelitian untuk mencapai hal yang mempunyai isntrumen yang lebih valid serta variebel berbagai macam pemikiran yang ada. Adapun tujuan lain dari penelitian ini ialah agar mendapatkan instrumen yang mempunyai pemikiran sejarah dengan mengandalkan kriteria deminsi kognitif pada sebuah pembelajaran sejarah untuk perguruan tinggi. Disini juga dijelaskan beberapa metode yang dipakai untuk melakukan penelitan, diantaranya seperti analisis kebutuhan berdasarkan kompetensi pada kurikulum, melakukan rancangan sebuah 
instrumen untuk penilaian dalam berpikir sejarah, dan juga tidak lupa agar melakukan uji coba terhadap instrumen yang di hasilkan.

\section{Simpulan Konseptual Anotasi Bibliografi}

Didalam jurnal ini memuat berbagai hal yang bisa menjelaskan tentang bagaimana caranya menggunakan media untuk sebuah pembelajaran pada smartphone yang dimiliki, dengan menggunakan siswa untuk tujuan mengetahui apakah siswa bisa menggunakan smartphonennya untuk media sebelum dan sesudah siswa diberi penjelasan untuk kegunaan menggunakan media pada smarphone.

Didalam buku ini mencakup semua media yang bisa digunakan untuk melakukan berbagai macam pembelajaran untuk membuat peserta didik lebih memahami materi yang disampaikan, ataupun untuk mempermudah melakukan sebuah pembelajaran dengan menggunakan berbagai macam media yang ada di sekitar yang bisa di manfaatkan, salah satunya media eletronik yang tentu saja pada saat ini hampir seluruh orang mempunyai nya.

Dan yang terakhir artikel ini memberikan kita sebuah pemasukan pikiran agar kita mengetahui bagaimana cara kita berpikir yang baik untuk melakukan pembelajaran sejarah yang bisa membuat peserta didik berpikir kritis serta tidak baku dalam pembelajaran sejarah, dan juga untuk mendapatkan instrumen pemikiran yang valid dan variebel untuk tujuan sebuah pembelajaran pada perguruan tinggi. 